\title{
A Holocene environmental record reflecting vegetation, climate, and fire variability at the Páramo of Quimsacocha, southwestern Ecuadorian Andes
}

\author{
Nele Jantz $\cdot$ Hermann Behling
}

Received: 30 March 2011 / Accepted: 5 October 2011/Published online: 20 October 2011

(C) The Author(s) 2011. This article is published with open access at Springerlink.com

\begin{abstract}
We reconstructed the palaeoenvironmental conditions of the last ca. 8,000 years in the Tres Lagunas region of the Quimsacocha volcanic basin (ca. 3,800 m a.s.l.) in the southwestern Ecuadorian Andes. By means of a pollen and charcoal record, we analysed vegetation, fire, and climate history of this area, which is sensitive to climatic changes of both the Pacific as well as of the eastern Andes and Amazon region. Sediment deposits, pronounced increases of pollen and charcoal concentrations, and pollen taxa reflect warmer and drier conditions in the early to midHolocene ( $~ 8000$ to $3900 \mathrm{cal}$. B.P.). During the late Holocene (2250 to -57 cal. B.P.), five warm and cold phases occurred at Quimsacocha. The most prominent cold phase possibly corresponds to the globally recognized Little Ice Age (LIA; $\sim 600$ to 100 cal. B.P.). The cold phase signal at Quimsacocha was characterized by a higher abundance of Poaceae, Isoëtes and Gentianella, which are favoured by cold and moist conditions. Frequent charcoal particles can be recorded since the early to mid-Holocene ( 7600 в.Р.). The high Andean tree species Polylepis underwent several phases of degradation and re-establishment in the basin, which could indicate the use of fire by pre-Columbian settlers to enhance the growth of preferred herb species. The Tres Lagunas record suggests that human populations have been influencing the environment around Quimsacocha since the last ca. 8,000 years.
\end{abstract}

Communicated by E.C. Grimm.

N. Jantz $(\varangle) \cdot$ H. Behling

Department of Palynology and Climate Dynamics,

Albrecht-von-Haller Institute for Plant Sciences,

University of Göttingen, Untere Karspüle 2,

37073 Göttingen, Germany

e-mail: nele.jantz@biologie.uni-goettingen.de
Keywords Palaeoecology $\cdot$ Holocene $\cdot$ Climate change . Páramo $\cdot$ Andes $\cdot$ Ecuador

\section{Introduction}

The Ecuadorian Andes are important: (i) Ecologically because of high diversity (both alpha and beta) and endemism (Balslev and Luteyn 1992; Jørgensen and León-Yánez 1999; Luteyn 1999) and (ii) for the provision of ecosystemservices, such as the regulation of Andean hydrology, protection from erosion and the provision of food for a growing population. However, the landscapes of the Ecuadorian Andes suffer a high degradation rate. Ecuador has the highest deforestation rate in South America (Mosandl et al. 2008; Sarmiento 2002), and Páramo areas especially of lower altitudes are subject to overgrazing, fire or cultivation, which lead to reduction of biodiversity and water retention capacity, as well as to soil erosion (Podwojewski et al. 2002). The development of useful and innovative protection strategies in the Ecuadorian Andes is consequently urgently needed. In this context, the knowledge of palaeoecological conditions can be of crucial importance, as the composition of past natural as well as of pre-Columbian anthropogenic landscapes and climate conditions are often not well known. Several palaeoecological studies have been carried out in the eastern tropical Andes (e.g. Brunschön et al. 2010; Hillyer et al. 2009; Niemann and Behling 2008), whereas there are only a few studies that deal with the conditions on the western Cordillera (e.g. Colinvaux et al. 1997; Hansen et al. 2003; Weng et al. 2006). In general, there is a trend of a warm and dry early to mid-Holocene in the west and central Andes region of Ecuador, Peru and Bolivia (Hansen et al. 2003; Paduano et al. 2003; Weng et al. 2006). However, there are still uncertainties concerning the magnitude and time span of 
this mid-Holocene dry event. A time-transgressive reoccurrence of moister conditions from north to south seems to be evident for the Central Andes region of Peru and Bolivia. A longer and more severe dry phase from 6000 to 2400 cal. B.P. is reported from central Bolivia (Taypi Chaka Kkota, $16^{\circ} \mathrm{S}$, Abbott et al. 2003), whereas sediments from Laguna la Compuerta $\left(7^{\circ} \mathrm{S}\right)$ in northern Peru show a shorter dry phase from 10000 to 5500 cal. B.P. (Weng et al. 2006). In some parts of the southern tropical Andes region, the midHolocene dry event does not seem to be as pronounced and some palaeorecords show volatile lake levels rather than a complete drying-out, as for example Hillyer et al. 2009 and Valencia et al. 2010 for Laguna Pacucha in Southern Peru $\left(13^{\circ} \mathrm{S}, 3,095 \mathrm{~m}\right.$ a.s.1.). To what extend the western cordillera of the Ecuadorian Andes was subjected to the mid-Holocene dry event remains yet to be determined due to an absence of published studies.

The late Holocene is marked as a moister period with repeated climatic oscillations for most tropical Andean sites, such as Lake Titicaca and Taypi Chaka Kkota in Bolivia (Abbott et al. 2003). During this period, human influence is reported throughout the Andes. Weng et al. (2006) date human influence back to least 5500 cal. B.P. for Laguna Compuerta in northern Peru and Bush et al. (2005) suggest occasional human influence from $6000 \mathrm{cal}$. B.P. at Laguna de Chochos, about $200 \mathrm{~km}$ northeast of Laguna Compuerta. In the southwestern Ecuadorian Andes, traces of human land use are present in the pollen records of Laguna Pallcacocha and Lagunas Chorreras since $\sim 4000$ cal. B.P. (Hansen et al. 2003).

In this paper, we present results of palaeoecological investigations from the Tres Lagunas region in the Quimsacocha volcanic basin in south Ecuador, which, due to its situation on the eastern ridge of the western Cordillera, is sensitive to climatic changes of both the Pacific as well as of the eastern Andes and Amazon region.

Our main objective is to detect climatic patterns of regional to global significance since the early to midHolocene. We will asses the role of the mid-Holocene dry phase, as well as late Holocene climatic patterns for this part of the tropical Andes region. Furthermore, we will integrate our results into a more regional comparison of records. We will also reconstruct regional vegetation and fire dynamics and assess the history of anthropogenic impact of the Quimsacocha volcanic basin.

\section{Study region}

\section{Geomorphology}

The regional geomorphology was shaped by glacial activity, persisting until the late Pleistocene ( 126000-11800 в.P.). Characteristic features include U-shaped valleys, numerous small lakes, and moraines (Rodbell 2002; Hansen et al. 2003). Even though a few studies on past vegetation (Colinvaux et al. 1997; Hansen et al. 2003) and soils (Rodbell 2002; Harden 2007) have been carried out in the nearby Cajas National park area and surroundings, no absolute dates for the glacial retreat have been determined so far. However, by the means of pollen and sediment analyses, a glacial retreat has been recorded for the period between 17000 and $15000 \mathrm{cal}$. B.P. at the lakes Laguna Llaviucu (3,140 m a.s.1.), Laguna Chorreras (3,700 m a.s.1.) and Laguna Pallcacocha (4,060 m a.s.1.) (Hansen et al. 2003; Colinvaux et al. 1997).

\section{Potentially natural forest vegetation and land use}

Three major forest types have been recognised in the Podocarpus National Park today (about $200 \mathrm{~km}$ south of the study site) (Homeier et al. 2008). The evergreen lower mountain rainforest is found at altitudes from 1,300 to $2,100 \mathrm{~m}$ a.s.l. Here, trees grow up to $40 \mathrm{~m}$ in height and form dense vegetation that is enriched with many epiphytes and lianas. Typical plant families and genera are Arecaceae, Bignoniaceae (Tabebuia), Clusiaceae (Vismia), Lauraceae (Nectandra and Ocotea), Melastomataceae (Miconia), Moraceae (Ficus, Morus) and Piperaceae (Piper).

From ca. 2,100-2,700 m a.s.l. evergreen upper mountain rainforest grows on the more humid Andean slopes. Canopies reach a maximum height of about $25 \mathrm{~m}$ in this vegetation type and abundant taxa include Aquifoliaceae (Ilex), Chloranthaceae (Hedyosmum), Clethraceae (Clethra, Purdiaea), Cunoniaceae (Weinmannia), Cyatheaceae (Cyathea), Myricaceae (Myrica), Myrsinaceae (Myrsine) and Podocarpaceae (Podocarpus, Prumnopitys).

The Subpáramo, or elfin forest, forms the forestline ecotone with trees and shrubs of $8 \mathrm{~m}$ height at maximum. Characteristic taxa are Aquifoliaceae (Ilex), Bromeliaceae (Puya), Chloranthaceae (Hedyosmum), Cunoniaceae (Weinmannia), Clethraceae (Clethra), Loranthaceae (Gaiadendron), Ericaceae (Gaultheria), Melastomataceae (Graffenrieda) and Symplocaceae (Symplocos), as well as dense stands of the bamboo Chusquea (Poaceae).

In general, human activity has a big impact on the vegetation of the Andes in Ecuador, as land use patterns frequently involve grazing, burning and deforestation (Ramsay and Oxley 1996).

\section{Regional climate}

The climate of the study region is humid, tropical and montane, with strong winds and occasional frost. Climatic patterns are mostly controlled by the tropical trade wind regime with its easterlies carrying moisture from the 
Amazon basin, but local wind patterns are considerably modified by the topography of the Andes (Beck et al. 2008; Emck 2007). Because of the height reduction of the mountain chain and associated barrage effects of the Amazon trade winds, cloud frequency in the Andean depression is generally high at about $70-75 \%$, and a persistent fog belt below $3,600 \mathrm{~m}$ adds to precipitation (Bendix et al. 2004; Hansen et al. 2003).

Palaeoecological records from Lagunas Pallcacocha in the Cajas National Park, which is situated $50 \mathrm{~km}$ further north, but also on the eastern side of the western Cordillera, report the influence of El Niño Southern Oscillation on the site (Moy et al. 2002).

Study site

\section{Location}

The study area Tres Lagunas $\left(03^{\circ} 02^{\prime} \mathrm{S} 79^{\circ} 14^{\prime} \mathrm{W}\right)$ is located on the Quimsacocha volcanic plateau on the eastern ridge of the western Cordillera of the Andes in south Ecuador (Fig. 1). Situated about $30 \mathrm{~km}$ southwest of the city of Cuenca, it is thus close to the big Cajas massif.

This region comprises the northernmost part of the Andean depression between Girón-Cuenca in south Ecuador and Huancabamba in north Peru. Here, mountains barely reach heights of 4,000 $\mathrm{m}$ and no active volcanoes are present.

The core Tres Lagunas (TL) was taken from the shallow old volcanic basin Quimsacocha, which has a circular surface of ca. $8 \mathrm{~km}^{2}$ and is situated at an altitude of $3,780 \mathrm{~m}$ a.s.l.

\section{Geology}

The superficial rocks in the Quimsacocha region are of volcanic origin. At the TL site, the activity of the Quimsacocha volcano led to the Tarqui-formation which was formed during the late Miocene to Plio-Pleistocene and contains various lithologies, such as ashflow tuffs, rhyolithic to andesitic volcanic breccias, pyroclastic flows and ignimbrites. Intermediate to acid pyroclastics have partly converted to dark red and purple kaolinitic clays in the upper part of the formation (Hungerbühler et al. 2002).

\section{Soils}

The most important soil types of the Páramo are Andosols and Histosols, defined by the content of volcanic ashes in the soil. Both soil types are generally characterised by dark epipedons which contain high amounts of organic material and have a loose granular to subangular blocky structure with a very low bulk density $\left(400 \mathrm{~kg} \mathrm{~m}^{-3}\right)$. Furthermore,



Fig. 1 a Map of Ecuador in South America. b Map of Ecuador, Colombia, Peru and Bolivia with sites mentioned in the text. Paleoecological records: star study site Tres Lagunas, $a$ Turbera de Calostros, $b$ Lagunas Chorreras, $c$ Laguna Pallcacocha, $d$ El Tiro, $e$ Cerro Toledo, $f$ Laguna de Chochos, $g$ Laguna la Compuerta, $h$ Laguna Pacucha, $i$ Laguna Titicaca, $j$ Taypi Chaka Kkota, $k$ Laguna el Junco (Galapagos). Archeological sites: 1 El Inga, 2 Cubilan, 3 Chobshi cave. c Map of Cuenca and the Tres Lagunas region in the Quimsacocha volcanic basin. Source: Planiglobe Beta (www.planiglobe.com, Creative Commons Attribution 2.5 License)

the soils are marked by a very high water retention capacity with values of up to more than 100\% (Buytaert et al. 2005).

\section{Modern climate}

The mean annual rainfall in the Quimsacocha region is $1,280 \mathrm{~mm}$, but precipitation shows high seasonal variability. The most humid months are November, March and April with a precipitation of about $250-280 \mathrm{~mm}$, whereas in the driest months of August and December the precipitation is very low at about $20 \mathrm{~mm}$ (AMBIGEST 2005). 
Temperatures vary on a diurnal basis between 12 and $19^{\circ} \mathrm{C}$ during the day and 2 to $-3^{\circ} \mathrm{C}$ at night. The prevailing winds $(59 \%)$ are from the northeast with wind speeds from 3 to $5.1 \mathrm{~m} / \mathrm{s}$ (AMBIGEST 2005).

\section{Modern vegetation and land use}

The vegetation surrounding the study site is Páramo, which is typically dominated by tussock plants, along with acaulescent rosettes, erect and prostrate herbs (Ramsay and Oxley 1997). The tussock Páramo at this site is dominated by bunch-grasses of the genera Stipa and Calamagrostis (both Poaceae). Other recorded abundant genera with various species include Hypericaceae (Hypericum), Poaceae (Paspalum, Cortaderia), Valerianaceae (Valeriana), Asteraceae (Baccharis, Chuquiragua, Gynoxys, Diplostephium, Werneria, Loricaria), Apiaceae (Eryngium, Hydrocotyle), Gentianaceae (Gentianella, Halenia), Geraniaceae (Geranium), Lycopodiaceae (Huperzia), Pteridaceae (Jamesonia), Fabaceae (Lupinus), Campanulaceae (Lysipomia) and Bromeliaceae (Puya) (AMBIGEST 2005; personal observation). Cushion forming Plantaginaceae (mostly Plantago rigida) and Cyperaceae (Uncinia) are typically found in moist depressions of higher elevated Páramo sites (Bosman et al. 1994).

The vegetation of the study site is strongly influenced by the topography of the Andes and the resulting environmental conditions, such as the strong variability of rainfall, wind and temperature. The whole Quimsacocha basin is used as pasture for llamas and alpacas and surface fires are often used by the local farmers to remove unwanted vegetation such as tufts of Calamagrostis (personal observation, Fig. 2).

On lower elevation Páramo sites, vast areas of exotic tree plantations with Pinus spp. and Eucalyptus spp. have been established over the past decades and are now a prominent feature of the Andean landscape (Hofstede et al. 2002; Farley 2007; Sarmiento 2002). Besides this, the fastgrowing Peruvian high-altitude species Polylepis racemosa has been introduced and planted in the Páramos of Quimsacocha.

\section{Methods}

\section{Coring and dating}

A sediment core $144 \mathrm{~cm}$ in length was taken with a Russian corer in a peat bog at the Tres-Lagunas site in September 2007 (surface sample, $-57 \mathrm{yr}$ B.P.). Three sections $50 \mathrm{~cm}$ long were stored in PVC tubes. The core was kept under dark and cold $\left(+4^{\circ} \mathrm{C}\right)$ conditions at the Department of Palynology and Climate Dynamics at the University of Göttingen (Germany) before processing. Six samples of organic material were taken for Accelerator

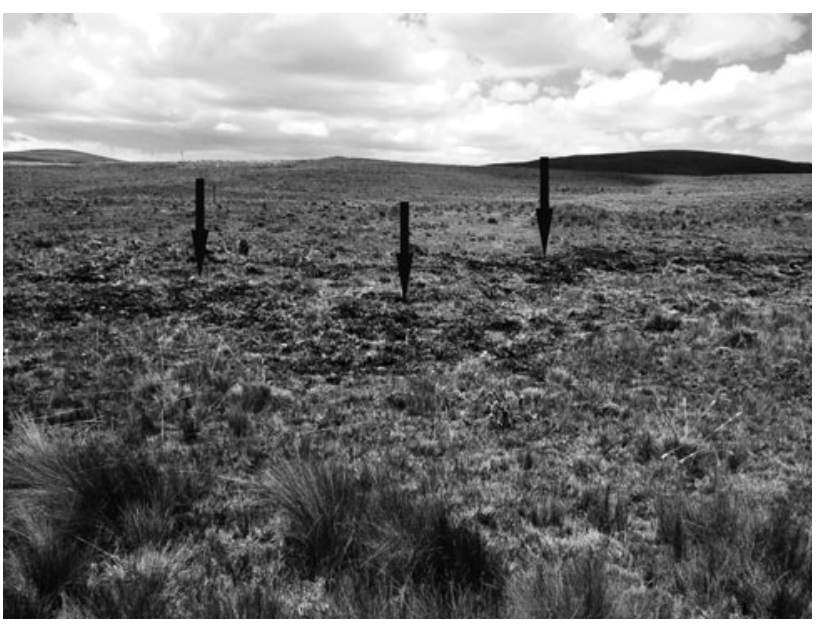

Fig. 2 Photograph of the Quimsacocha volcanic basin with arrows marking traces of recent fire activity

Mass Spectrometry (AMS) radiocarbon dating and sent to the University of Erlangen-Nürnberg and to the Poznan Radiocarbon Laboratory. Sample ages were calibrated using Calpal online and the Calpal 2007 HULU curve for the Northern Hemisphere (Weninger et al. 2010).

Sedimentation rates were calculated for each interval between two calibrated radiocarbon datings (except for the outlier). The surface was set to be of an age of -57 в.P. To show the greatest differences possible for the given dates, we calculated minimum, average and maximum sedimentation rates. For the maximum rate, the estimated minimum of the earlier date and the estimated maximum of the later date were taken, for the average rate the estimated average dates were taken, and for the minimum sediment accumulation rate the estimated maximum of the earlier date as well as the estimated minimum of the later date were used for analysis.

\section{Sample processing and analysis}

For the extraction of pollen, spores and charcoal, 58 subsamples with a volume of $0.25 \mathrm{~cm}^{3}$ sediment were taken from the core at distances of $2 \mathrm{~cm}$ apart, from the surface $(0 \mathrm{~cm})$ down to $142 \mathrm{~cm}$. Processing was carried out using standard pollen analytical methods, modified from Fægri and Iversen (1989). One tablet of Lycopodium clavatum, containing $18,583 \pm 762$ spores, was added to each subsample to enable the calculation of pollen concentration. Samples were generally counted to a minimum of 300 pollen grains. The pollen sum excludes ferns and mosses, including Isoëtes, as well as undetermined taxa. For one sample $(114 \mathrm{~cm})$, grains could only be counted up to a total number of 100 due to very low pollen concentration. Below $114 \mathrm{~cm}$ core depth, samples were not analysed, because pollen concentration was very low and preservation of the grains was not sufficient. For the 
determination of pollen and spore taxa, the reference collections of Ecuador (containing ca. 400 taxa) and Brazil (containing ca. 3,000 taxa) of the Department of Palynology and Climate Dynamics, University of Göttingen, were used. Support for determination was also given by the electronic pollen keys of Ecuador and southern Brazil kept at the department, as well as by the Southern American Pollen Database (Bush and Weng 2007) and by literature (Hooghiemstra 1984; Roubik and Moreno 1991). All pollen types were attributed to groups that either correspond to different vegetational units (Lower Mountain Rainforest, Upper Mountain Rainforest, Subpáramo, Páramo) or had to be grouped due to lack of information or by correspondence to other groups (others, ferns and mosses as well as unknown and indeterminate taxa). A full list of the taxa groupings can be found in Table 1 .

For charcoal analysis, a traverse of the middle of the slide was made and charcoal particles and markers were counted up to a total of 100 Lycopodium clavatum spores to ensure a charcoal concentration estimate with an error of less than 5\% (Finsinger et al. 2008). In samples with a very high pollen concentration (Sample numbers 52-57, $102-112 \mathrm{~cm}$ ), charcoal was only counted up to a total count of ten markers and then multiplied by ten. Furthermore, the counted charcoal particles were attributed to one of five groups of different particle sizes so as to give more detailed evidence about the fire history in terms of distance of fires from the study site (Whitlock and Larsen 2001; Sadori and Giardini 2007). Therefore groups of particle sizes from 10-25 $\mu \mathrm{m}, 25-50 \mu \mathrm{m}, 50-100 \mu \mathrm{m}$ and $>100 \mu \mathrm{m}$ were created. Charcoal particles were measured taking their longest axis (Whitlock and Larsen 2001).

\section{Data analysis}

By means of the program TILIA (Grimm 1987), taxa were placed in the groups mentioned above. Sums, percentages, and pollen and charcoal concentration (grains, respectively particles $\mathrm{cm}^{-3}$ ), were then calculated with the same program. The results were depictured using TILIAGRAPH, and pollen zones were created by means of the program CONISS based on a cluster analysis using the total sum of squares (Grimm 1987). Only the pollen grains that contributed to the total pollen sum of 300 were included in this analysis, as this gave the best fit with stratigraphy.

Multivariate data analysis was carried out on pollen percentage data using the programmes Canoco for Windows 4.5 and CanoDraw for Windows 4.13 (ter Braak and Šmilauer 2002). All pollen taxa which were present in at least 2 samples in one of which a percentage value of $>1 \%$ was reached were included in the analysis to decrease the effect of rare taxa that do not explain the overall vegetation trend well. First, a detrended correspondence analysis
(DCA) was conducted to determine the length of the environmental gradient, which had a value of only 1.305 . Thus a linear model could explain and depict the data in a more comprehensive way. We therefore carried out a principal components analysis (PCA). For both analyses, data were transformed using square-root transformation. This removes the emphasis from very dominant taxa and improves the fit of the count data.

\section{Results}

\section{Stratigraphy}

The stratigraphy of the sediment is shown in Fig. 4b. From the bottom of the core at $130 \mathrm{~cm}$ up to a depth of $111.5 \mathrm{~cm}$, almost no organic matter is present in the sediment. Silty clay and sand particles dominate this part of the core which has a greyish colour with light brown bands. From 111.5 to $98 \mathrm{~cm}$, the sediment becomes a much more compact and decomposed dark brown peat. From 98 to $23 \mathrm{~cm}$ the main component of the sediment is decomposed, peaty organic material, yet few plant remains are visible. From a depth of $23 \mathrm{~cm}$ to the surface, the sediment consists of poorly decomposed brownish plant material.

\section{Chronology and pollen zonation}

Five radiocarbon dates were used to create a chronology for the Tres Lagunas core (Table 2). Dating was based on organic material (peat), which was cleaned from roots and rootlets. The assumption that the surface is modern could be verified by pollen analysis, as pollen of the exotic genus Pinus was found in the uppermost sample. The base of the core dates back to the early Holocene with an age of $8428 \pm 41$ cal. B.P. at $141 \mathrm{~cm}$ depth. However, the base of the section analysed $(114 \mathrm{~cm})$ is of an age of approximately $7750 \mathrm{cal}$. B.P.

The age-depth relationship of the core is consistent with the exception of one outlier at $48-48.5 \mathrm{~cm}$ core depth, which is dated as $-144 \pm 50$ cal. B.P. This radiocarbon age was disregarded for the construction of the age depth model because of its incompatibility with the other age data obtained (Table 2); we interpret the anomalously young age of the $48.5 \mathrm{~cm}$ sample as a product of root activity moving young carbon down through the stratigraphy. Sedimentation rates were not constant through time (Fig. 3), but for most of the core they stay in the range from 1.9 to $6.2 \mathrm{~mm} \mathrm{year}^{-1}$. However, sediment accumulation decreases by an order of magnitude from 98.5 to $110.5 \mathrm{~cm}$ to very low rates of $0.22 \mathrm{~mm}_{\text {year }}{ }^{-1}$. Therefore, we take into account a hiatus from $7672 \pm 37 \mathrm{cal}$. B.P. to $2242 \pm 66$ cal. B.P., which is supported by an abrupt change of the sediment structure (see grey bars indicated in 


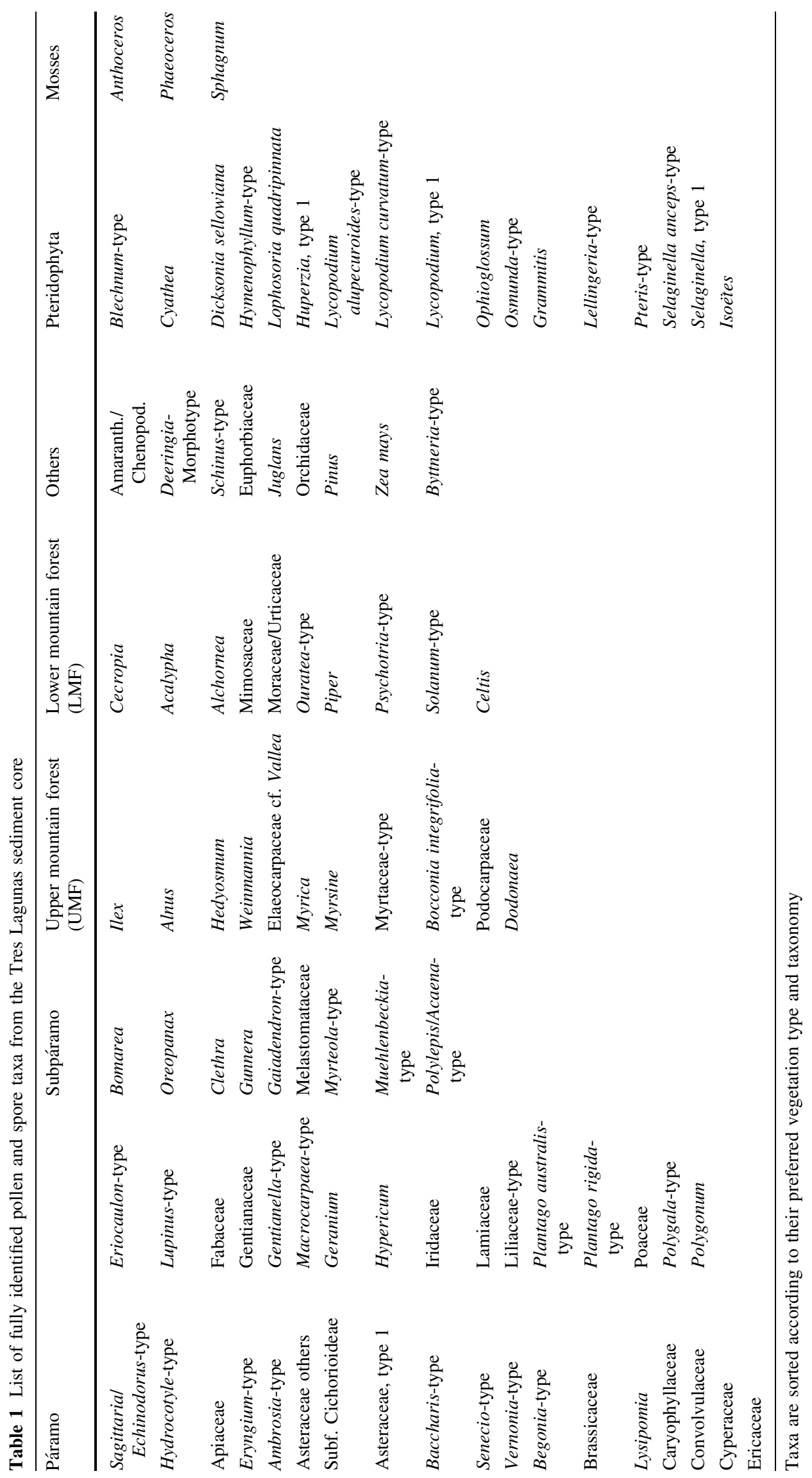


Table 2 AMS Radiocarbon dates, calibrations, sediment accumulation rates and type of material used for dating of samples from the Tres Lagunas sediment core

\begin{tabular}{|c|c|c|c|c|c|c|}
\hline Lab. no. & $\begin{array}{l}\text { Depth } \\
(\mathrm{cm})\end{array}$ & $\begin{array}{l}{ }^{14} \mathrm{C} \text { age } \\
\text { (year в.P.) }\end{array}$ & $\begin{array}{l}\text { Calibrated age } \\
\text { (cal. year } \\
\text { B.P. })^{\mathrm{a}}\end{array}$ & $\begin{array}{l}1 \sigma \text {-range } \\
\text { (cal. year } \\
\text { B.P.) }\end{array}$ & $\begin{array}{l}\text { Sediment } \\
\text { accumulation } \\
\text { rates (min-max) } \\
\text { [mm/year] }\end{array}$ & Type of material dated \\
\hline Erl-13827 & $48-48.5$ & $-144 \pm 50$ & - & - & - & Decomposed organic material with rootlets \\
\hline Erl-12178 & $70-70.5$ & $1143 \pm 41$ & $1063 \pm 63$ & $1000-1126$ & $0.63-0.71$ & Peaty, strongly decomposed material \\
\hline Erl-12487 & $90-90.5$ & $2125 \pm 41$ & $2118 \pm 70$ & $2048-2188$ & $0.17-0.22$ & Peaty, strongly decomposed material \\
\hline Erl-13828 & $98.5-99$ & $2224 \pm 45$ & $2242 \pm 66$ & $2176-2308$ & $-7.08^{\mathrm{c}}-0.33$ & Decomposed organic material with rootlets \\
\hline Poz-24269 & $110-111$ & $6840 \pm 40$ & $7672 \pm 37$ & $7635-7709$ & $0.02-0.02$ & Peaty, strongly decomposed material \\
\hline Erl-12179 & $141-142$ & $7611 \pm 53$ & $8428 \pm 41$ & $8386-8469$ & $0.37-0.46$ & $\begin{array}{l}\text { Clay with limnic material and plant } \\
\text { residues }\end{array}$ \\
\hline
\end{tabular}

Sedimentation rates refer to the time span between the calibrated radiocarbon date in the same row and that in the row above; for the first sedimentation rate an age of -57 for the top sample $(0 \mathrm{~cm})$ was assumed

a The calibrated age is the mean probability of the range of $1 \sigma$. Calibration is based on the Calpal 2007 HULU curve for the Northern Hemisphere (Weninger et al. 2010)

b Date treated as an outlier, not considered for age-depth model or sediment accumulation rates

${ }^{c}$ The negative value is a result of overlapping radiocarbon datings which cause the sedimentation rate to be negative when taking the maximum date of one age and the minimum of another

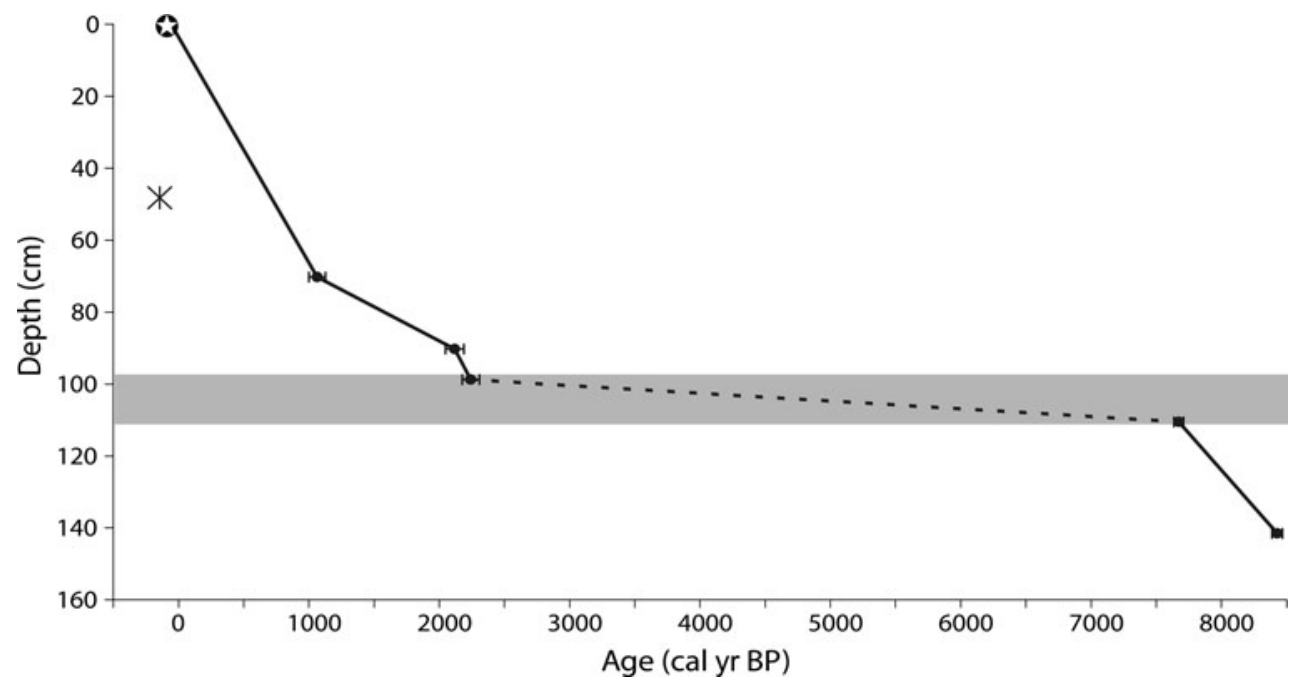

Fig. 3 Age-depth relationship (linear interpolation, cal. year в.P./core depth in $\mathrm{cm}$ ) based on 5 radiocarbon dates and the surface sample ( -57 cal. year B.P., marked by a star). The outlier at $48.25 \mathrm{~cm}$ is

Figs. 3 and 4). The cluster analysis helped to determine six pollen zone divisions, including one subdivision (Fig. 4b).

\section{Pollen zone description}

Zone TL-I (114-97 cm; 9 samples, 7800-2250 cal. B.P.)

The later part of the early Holocene and the whole midHolocene are represented here. Thus, this zone is characterised by mostly very high pollen concentration values of depicted as an asterisk; the possible hiatus from $2242 \pm 66 \mathrm{cal}$. year B.P. to $7672 \pm 37$ cal. year в.P. is indicated by a dotted line and a shaded band

up to $4,380,000$ grains $\mathrm{cm}^{-3}$ which correlate with sedimentation rates of $0.02 \mathrm{~mm} \mathrm{year}^{-1}$. Also, the highest charcoal concentration values are reached in this zone. The pollen composition of this zone is different to that throughout the upper parts of the core, with relatively high values of Plantago rigida-type (17-10\%) and Apiaceae (2-7\%), as well as the presence of Valeriana, Gentianellatype, Baccharis-type and Lysipomia (all 2-4\% at maximum) at the bottom of the zone. Although Poaceae $(29-48 \%)$ is the most abundant pollen taxon, a high variety 
Fig. 4 Pollen diagram of core TL (Tres Lagunas, 3,780 m, Quimsacocha volcanic basin, south Ecuador). A period of possible hiatus is indicated by a shaded band. a Percentage data for the most important taxa grouped into Páramo,

Subpáramo, Upper mountain forest (UMF), lower mountain forest (LMF), others, and pteridophyta. The age scale is based on calibrated years before present. The sample at $114 \mathrm{~cm}$ depth was counted to a total pollen sum of 100 ; $\mathbf{b}$ percentage sums of ecological groups and records of pollen and charcoal concentrations (particles $\mathrm{cm}^{-3}$ ), as well as stratigraphy of the core, the total pollen sum and the CONISS cluster analysis

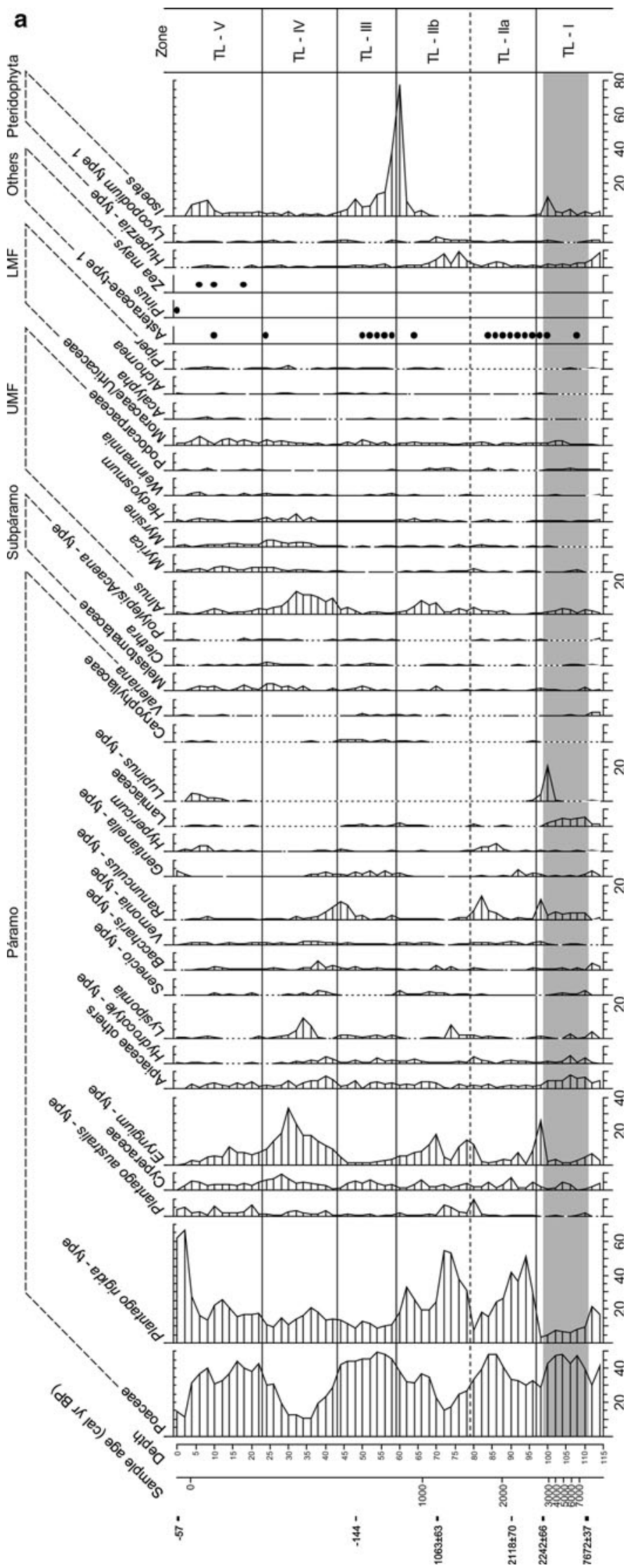


Fig. 4 continued

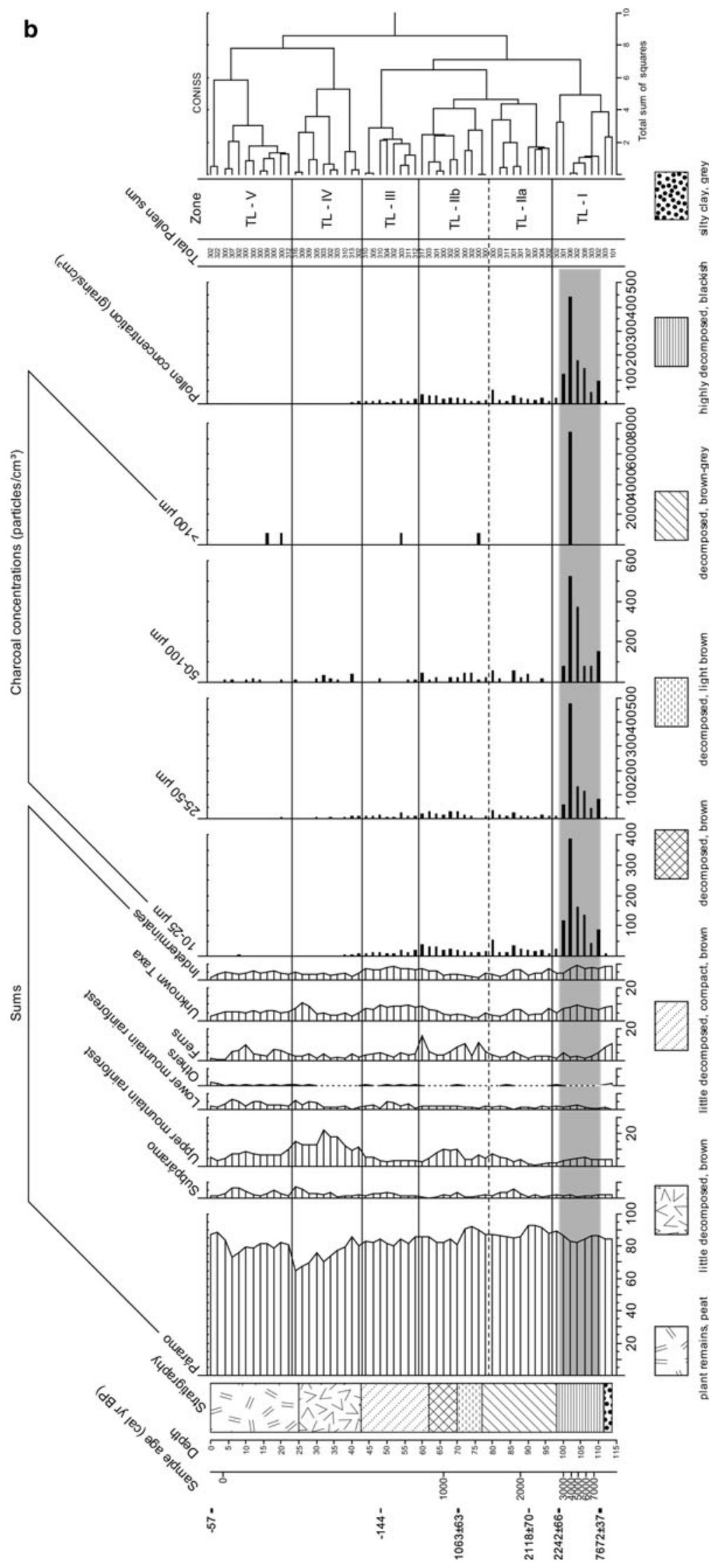


of other taxa, such as Lamiaceae (0-6\%), Lupinus-type (0-21\%), Ranunculus-type (0-12\%), Senecio-type (0-3\%) and Hydrocotyle-type (0-5\%) account for the composition of the diversity. Fern spores show highest values at the bottom of this zone, mostly due to Huperzia (9-3\%), while values of Isoëtes reach $11 \%$ at the top of the zone.

\section{Zone TL-II (97-59 cm, 19 samples, 2250-800 cal. B.P.)}

This zone is divided into the subzones TL-IIa $(97-79 \mathrm{~cm}, 9$ samples, 2250-1600 cal. B.P.) and TL-IIb (79-59 cm, 10 samples, 1600-800 cal. B.P.). However, both zones are characterised by a marked decrease in pollen and charcoal concentration (80,000-380,000 grains $\mathrm{cm}^{-3}$ for pollen, and $70,000-350,000$ particles $\mathrm{cm}^{-3}$ in the smallest charcoal fraction).

Poaceae and Plantago rigida-type are the most prominent pollen taxa, but with varying relative abundances. Pollen of Plantago rigida-type (29-51\%) shows generally higher values than Poaceae pollen (30-33\%) at the base of subzone TLIIa, whereas at the top, the pattern is reversed with 34-49\% Poaceae pollen compared to 8-26\% Plantago rigida-type pollen. An unknown but characteristic pollen type of Asteraceae reaches values up to $2 \%$ during this zone. Pollen percentages of Lupinus-type, Lamiaceae, Apiaceae, and Lysipomia decline and stay at very low values, whereas percentages of Hypericum-type (0-5\%), Ranunculus-type (up to $12 \%$ ) and Eryngium-type (up to 26\%) decrease at the base but rise again towards the end of the subzone TL-IIa, as do values of Plantago australis-type for the first time with only one sample of $10 \%$. Pollen of Polylepis-Acaena-type is present.

In subzone TL-IIb percentages of Eryngium-type (3-18\%) generally increase, whereas values of Poaceae and Plantago rigida-type remain fluctuating. Proportions of Plantago australis-type pollen remain higher at the base of the subzone (2-7\%) but decline towards the top.

Tree taxa (up to $10 \%$ ) reach higher values, mostly on account of slightly increased percentages of Podocarpaceae, Weinmannia, Hedyosmum (all 0-2\%) and Alnus (1-8\%) pollen. Fern and moss taxa also increase in percentages (up to 15\%), due to higher proportions of spores of Huperzia-type (1-9\%) and Lycopodium-type (0-3\%). Values of Isoëtes peak at the end of the zone and reach $78 \%$.

Zone TL-III (59-43 cm, 8 samples, 800-650 cal. в.P.)

Pollen (ca. 208,000-64,000 grains $\mathrm{cm}^{-3}$ ) and charcoal concentrations (ca. 164,000-59,000 particles $\mathrm{cm}^{-3}$ for the smallest fraction) decrease further throughout this zone.

Pollen taxa composition changes considerably. Percentages of Eryngium-type (1-5\%), Plantago rigida-type (8-13\%), and Senecio-type (0-1\%) decrease markedly, whereas Poaceae (42-49\%), Lysipomia (0-2\%), Gentianella-type (1-4\%), Caryophyllaceae and Baccharis-type (1-2\%) increase in value. Ranunculus-type pollen shows higher abundance towards the top of the zone with a peak of $11 \%$ in the last sample.

Percentages of Alnus decrease to $1-4 \%$. However, values of Weinmannia show a small increase to a maximum of $2 \%$. A slight increase of Moraceae/Urticaceae pollen (0-3\%) and the more continuous presence of Alchornea, Acalypha and Piper pollen is recorded. Lower values of Huperzia and Lycopodium (1-4\%) lead to a decreased proportion of the fern and moss group. Percentages of Isoëtes remain high at first, but decline towards the top (38-3\%).

\section{Zone TL-IV (43-23 cm, 10 samples, 650-300 cal. B.P.)}

Poaceae pollen decreases to a minimum level of $10 \%$ in the middle of the zone. Plantago rigida-type stays at lower values. Pollen of most other herb taxa increases in value: Eryngium-type (9-34\%), Cyperaceae (1-9\%), Lysipomia (0-12\%), Apiaceae (1-8\%), Hydrocotyle-type, Baccharistype, Senecio-type and Vernonia-type (all 0-5\%) show their highest percentages in this zone. Melastomataceae pollen increases in percentage and values of Clethra show a small peak. Except for Podocarpaceae, the abundances of all tree taxa increase towards the top of the zone $(0-4 \%)$. Particularly high values are shown by Alnus (3-14\%).

\section{Zone $T L-V(23-0 \mathrm{~cm}, 12$ samples, 300 to -57 cal. в.P.)}

This uppermost zone is characterised by the lowest pollen (16,000-6,000 grains $\left.\mathrm{cm}^{-3}\right)$ and charcoal (14,000-4,000 particles $\mathrm{cm}^{-3}$ ) concentration values. Percentages of Poaceae $(11-44 \%)$ increase at the bottom and of Plantago rigida-type (18-66\%) at the top of the zone. Most other taxa show lower values, but Hypericum (0-4\%), Gentianella-type and Lupinus-type increase in percentages (both 0-4\%). Proportions of Alnus decrease to 0-4\%. Fern and moss spores $(1-10 \%)$ increase in percentages. Most tree taxa remain stable in their values, but pollen of Moraceae/ Urticaceae increases further. Pollen of Zea mays-type and Pinus is present for the first time.

Multivariate data analysis

The PCA revealed the relationships between samples and taxa (Fig. 5). Only 19 of 35 included taxa are displayed, these having a species fit range of 10-100\%, meaning that only those taxa are shown for which the axes explain the percentage variability of the species data to at least $10 \%$. The eigenvalues are 0.251 for axis 1 and 0.208 for axis 2 . Envelopes around the samples of each zone indicate the 
Fig. 5 Results of the PCA of square-root transformed percentile pollen data from the Tres Lagunas region in the Quimsacocha volcanic basin in south Ecuador. Included are all samples and the taxa that had a species fit range of $10-100 \%$. Numbers correspond to sample depths, taxa are depicted with an arrow. Envelopes mark the outer border of the samples of each zone (I, II, III, IV, V). Taxa abbreviations: Alnus, Alnus; Api_oth, Apiaceae excluding Hydrocotyle and Eryngium-type; Ast1, Asteraceae type 1; Bacch, Baccharis-type; Cyp, Cyperaceae; Eryn, Eryngiumtype; Fab_Lup, Fabaceae Lupinus-type; Hedy, Hedyosmum; Lami, Lamiaceae; Lysip, Lysipomia-type; Mela, Melastomataceae; Myric, Myricaceae; Myrs,

Myrsinaceae; Pinus, Pinus; Pla_aus, Plantago australistype; Pla_rig, Plantago rigidatype; Poa, Poaceae; Ran, Ranunculus-type 1; Vern, Vernonia-type

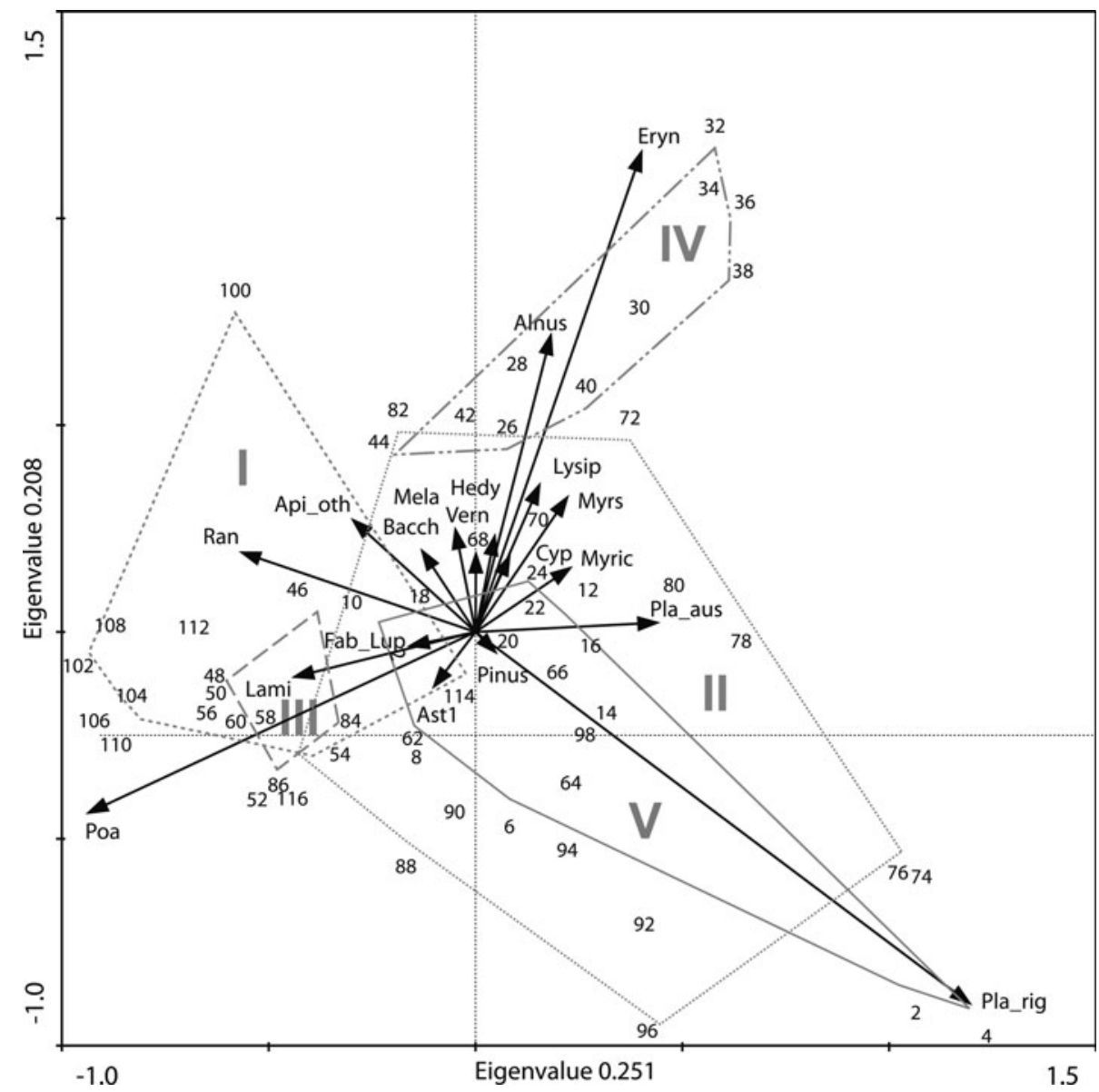

main differences in vegetation composition of the different zones. Plantago rigida-type is the taxon with the highest explanatory value and corresponds best to zone TL-V. The taxon that shows the best relation to Plantago rigida-type is Pinus. However, many other taxa, like Baccharis-type, Melastomataceae, Ranunculus-type, and Apiaceae are negatively correlated with these two taxa. Also, the first zone, TL-I, is negatively correlated to zone TL-V. Alnus and Eryngium-type have a neutral relationship with the groups mentioned before but show strong positive correlation with each other and correspond best to the samples of zone TL-IV. Taxa correlating positively with them are Lysipomia, Cyperaceae, Myrsine, Hedyosmum and Vernonia-type. Poaceae show high negative correlations with Myrica and Myrsine and correlate best with Lamiaceae, the unknown Asteraceae, and Lupinus-type.

\section{Interpretation and discussion}

\section{Early Holocene (7800-7700 cal. в.P.)}

The core derived from the Tres Lagunas-region of the Quimsacocha volcanic basin reflects local, regional and global vegetation dynamics since the early Holocene at ca. $7800 \mathrm{cal}$. B.P. As one date was too young at the top of the core $(-144$ B.P. at $48-48.5 \mathrm{~cm})$, root penetration that would have caused a bias towards younger dates cannot fully be excluded throughout the whole core. However, roots and rootlets have been removed from the material dated, and could only be recognized visually in the dated samples at $48-48.5 \mathrm{~cm}$ and $98.5-99 \mathrm{~cm}$ depth. The probability of contamination seems thus to be generally low in most samples. Even though the core reaches back further to a dated age of $8428 \pm 41$ cal. B.P., pollen could not be counted because of very bad pollen preservation and low pollen concentrations of $<5,000$ grains $\mathrm{cm}^{-3}$. This, together with the fact that the sediment below $111.5 \mathrm{~cm}$ depth in the core is compact silty clay with sand particles and little organic material, indicates erosion and an oxidising environment during the early Holocene. This could either be caused by repeated wet and dry cycles due to an enhanced seasonality (Tweddle and Edwards 2010), or by particularly high rainfall events that led to soil erosion (Wilmshurst and McGlone 2005). The lowermost counted samples had pollen spectra containing floristic components present in the Superpáramo (data not shown) which can today be found at altitudes from 4,100 to $4,500 \mathrm{~m}$ and 
contains shrubs of the genera Valeriana (Valerianaceae), Chuquiragua, Loricaria, Diplostephium, Pentacalia (Asteraceae), cushion plants like Plantago rigida (Plantaginaceae), Xenophyllum humile (Asteraceae), together with Azorella sp. (Apiaceae), herbs of the families of Lamiaceae and Fabaceae (Lupinus), as well as grasses of the genera Calamagrostis and Festuca (Poaceae). They are also characterised by lower biodiversity and the dominance of temperate and holarctic rather than of neotropical or cosmopolitan taxa (Sklenář and Ramsay 2001; Sklenáŕ 2005; Sklenár and Balslev 2007). High values of the genera Huperzia and Lycopodium found here could indicate disturbance (Brunschön and Behling 2009).

Early to mid-Holocene dry-event

(7700 to $\sim 2250$ cal. B.P.)

The next samples of the same zone are characterised by highly decomposed peaty sediment. The radiocarbon dates suggest that more than 5,000 years are represented in only $11 \mathrm{~cm}$ of sediment $(110.5 \mathrm{~cm}=7672 \pm 37 \mathrm{cal}$. в.P. to $98.75 \mathrm{~cm}=$ $2242 \pm 66$ cal. B.P.). This could have been caused by a hiatus which could have covered a large part of the mid-Holocene (as indicated by the grey marked section in Figs. 3 and 4). In addition to the compact sediment mentioned before, very high pollen and charcoal concentrations, which are up to an order of magnitude higher than in the samples immediately above, may also support the idea that the sediment accumulation rate was considerably low during the mid-Holocene. High pollen concentrations at this time period have also been noted by Bosman et al. (1994) for the Páramo of Turbera de Calostros in the eastern Cordillera of Colombia, and by Weng et al. (2006) for the western Cordillera of Peru. Also, Paduano et al. (2003) report higher pollen concentrations and influx values for the period between ca. 8000-3100 cal. B.P. from Lake Titicaca. A plausible explanation for this phenomenon would be a warmer climate that led to much faster peat decomposition (Coûteaux et al. 2002) and prevented sediment accumulation. Furthermore, drier conditions are known to increase the sensitivity of peat decomposition to temperature (Ise et al. 2008).

Due to the fact that an abrupt change of sedimentation rate, charcoal concentrations and stratigraphy took place, we suggest a hiatus in the sediment. Sediment hiatuses can indicate a complete drying out of the sediment. Hiatuses for the mid-Holocene have for example been reported from two shallow lakes (Lago Marcio and Lago Tapera) in the eastern Amazon basin region (De Toledo and Bush 2007). Here, the authors suggest they are mainly due to the low stand of the Amazon River during that time. This in turn would be caused by a major drought in the Andean watershed regions, such as the Quimsacocha volcanic basin.
A drier environment is also reflected in the pollen composition, with very high values of Poaceae and the presence of Senecio-type as well as of Baccharis-type and Alnus (most probably Alnus acuminata), which coincide with low levels of Plantago rigida-type pollen. Furthermore, a less humid environment is indicated by very high charcoal concentrations in this zone. Similar observations have been noted for Lagunas Chorreras in the Cajas National Park about $50 \mathrm{~km}$ northwards (Hansen et al. 2003) and the El Tiro Pass in the Podocarpus National Park further south (Niemann and Behling 2008). Human presence in the study area could be a possible reason for enhanced fire activity, as no active volcanoes are close by. On the other hand, the significance of the concentration of charred particles should not be overestimated. Due to the very low sedimentation rate, charcoal counts appear to be very high, even though they may not be much higher than in the rest of the core if one takes the time span into account. Also, a dry event could have led to more frequent fires, which in turn may have further enhanced decomposition by removing a proportion of the annual accumulating biomass, thus leading to a decreased sedimentation rate.

A drier early- to mid-Holocene has been recorded throughout many regions of the northern and central Andes. Marchant et al. (2002) report from a multi-proxy study across Colombia a general change to more xeric biomes with an onset occurring between 8500 and $4500 \mathrm{cal}$. B.P.

In Andean Ecuador, evidence for a drier period has been very scarce so far. Hansen et al. (2003) report higher fire frequencies due to the availability of woody fuel and warmer climatic conditions with moderate seasonality for the period between 10000 and 7500 cal. B.P. for Lagunas Chorreras and Laguna Pallcacocha in southwestern Ecuador $\left(2^{\circ} \mathrm{S}, 3,700\right.$ and. $4,060 \mathrm{~m}$ a.s.l. respectively). In southeastern Ecuador, there is no evidence for a major drought event. Brunschön and Behling (2009) report highest temperatures between ca. 9300 and 8500 cal. B.P. and at ca. $8000 \mathrm{cal}$. B.P. the replacement of Subpáramo vegetation with páramo vegetation (mostly Poaceae) at Cerro Toledo ( $4^{\circ} \mathrm{S}, 3,150 \mathrm{~m}$ a.s.l.). Here, however, continuously higher proportions of Sphagnum indicate moister conditions. At the El Tiro pass $\left(3^{\circ} \mathrm{S}, 2,810 \mathrm{~m}\right.$ a.s.l.), about $50 \mathrm{~km}$ north of Cerro Toledo, Páramo was replaced by Subpáramo vegetation, thus showing a contrary development (Niemann and Behling 2008). The authors suggest somewhat drier conditions, as fern spores decrease and charcoal influx increases.

In northern Peru, there is evidence for an early Holocene dry-event from 9500 to 7300 cal. B.P. in Laguna de Chochos $\left(7^{\circ} \mathrm{S}, 3,285 \mathrm{~m}\right.$ a.s.l.). At the nearby Laguna la Compuerta $\left(7^{\circ} \mathrm{S}\right)$, a shorter dry phase from 10000 to 5500 with a peak at about $8500 \mathrm{cal}$. в.P. is indicated, which coincided 
with the glacial recession from the lake catchment area (Weng et al. 2006).

At Lake Titicaca, southern Peru/Bolivia $(3,810 \mathrm{~m}$, $\left.16-20^{\circ} \mathrm{S}\right)$, a dry phase between ca. $9000-3100$ cal. B.P. with a peak between 6000 and $4000 \mathrm{cal}$. B.P. is recorded by Paduano et al. (2003) through a changing pollen composition that shows sharp decreases of concentrations of Cyperaceae and Isoëtes and a rise of taxa that can indicate saline conditions, such as Amaranthaceae/Chenopodiaceae. A more severe dry phase from 6000 to 2400 cal. B.P. is reported from central Bolivia (Taypi Chaka Kkota, $16^{\circ} \mathrm{S}$, Abbott et al. 2003).

Hillyer et al. (2009) and Valencia et al. (2010) record low lake levels from 10000 to 8700 cal. B.P. for Laguna Pacucha, south Peru $\left(13^{\circ} \mathrm{S}\right)$, which was followed by volatile lake levels from ca. 8300-5000 cal. B.P.

The underlying cause for this event is most probably a change of orbital parameters which resulted in a higher solar insolation during summer in boreal and equatorial regions (Berger and Loutre 1991). This could either have directly or indirectly caused a drier climate. Direct effects could have emerged through changes in the sea surface temperature (SST) gradient across the tropical Pacific, which would lead to strengthened easterly winds and a seasonally cooler eastern tropical Pacific (Clement et al. 2000). Indirect effects could have resulted from a more northern mean position of the Intertropical convergence zone (ITCZ), as is recorded by Haug et al. (2001). This would have led to stronger south-easterly trade winds, more oceanic upwelling, cooler SSTs and reduced precipitation (Conroy et al. 2008; Mitchell and Wallace 1991).

Abbott et al. (2003) detect a time-transgressiveness of the mid-Holocene dry event for the Andes, with more severe and longer droughts occurring in the central Bolivian Andes, and shorter and less intense dry phases for more northern sites. This seems to hold true, however there are still uncertainties about the time of the onset of moister conditions at the sites. Even though at the northernmost Peruvian sites investigated by Abbott et al. (2003), moist conditions returned as early as 4800 cal. B.P., this cannot be generalized as being true for all northern central Andes records. Our record indicates a much later onset of moist conditions at about $2250 \mathrm{cal}$. B.P. Results reported for the El Junco crater lake on the Galapagos Islands show that there, dry episodes occurred prior to $6000 \pm 10 \mathrm{cal}$. B.P. and at $5600 \pm 100 \mathrm{cal}$. B.P. but were also noticeable between $3800 \pm 40$ and $3200 \pm 160$ cal. B.P. Here, a twostep transition to higher lake levels from $3200 \pm 160$ and $2000 \pm 100$ cal. B.P. onwards is indicated (Conroy et al. 2008). Due to the possible hiatus in our record and the high sedimentation rate we cannot exclude a similar transition, which would well fit into the theory of less severe occurrences in the northern central Andes, which are possibly due to a progressively southward shift in the location and a strengthening of the wet season (Paduano et al. 2003).

Late Holocene (2250 to -57 cal. B.P.)

At the beginning of pollen zone TL-IIa (at ca. 2240 cal. B.P.), vegetation changes suggest a moister and cooler environment, as Plantago rigida-type becomes very abundant in the pollen spectrum while sediment accumulation together with pollen and charcoal concentrations decrease to much lower values. Other species, such as Ranunculus-type, Hypericum-type, and Plantago australistype also indicate humid surroundings.

However, one has to consider that pollen assemblages of peat bogs are typically dominated by pollen from vegetation within a few metres $(\sim 0.5-10 \mathrm{~m})$ of the sampling point, which can make an interpretation in terms of environmental changes on the regional scale difficult if peatland taxa are the dominant pollen type (Hicks et al. 2001; Bunting 2003).

In pollen zone TL-IIb, changes in pollen composition point to a drier climate, as Eryngium-type, Alnus, Huperzia-type and Lysipomia-type become more important pollen taxa. However, all these taxa can either point to drier conditions or to disturbance (Ayers 1997; Weng et al. 2004; Brunschön and Behling 2009). Taxa of the upper mountain rainforest also increase in abundance in this zone, and are thus indicating an upward shift of the upper forestline or a change towards windier conditions. The latter could not only explain the higher representation of forest taxa, but also the higher abundances of taxa that indicate drier conditions, as evaporation would be enhanced. In zone TL-III, a change towards a considerably moister and also colder environment is indicated. Very high values of Poaceae and Isoëtes, accompanied by raised values of Lamiaceae, Gentianella-type, Caryophyllaceae and Valeriana as taxa of mainly Superpáramo, as well as the decrease in upper mountain rainforest taxa, are characteristic of this period. Furthermore, multivariate analysis revealed that the samples of this zone are positively correlated to the first samples of zone I (Fig. 5). This cooling period could possibly relate to a period corresponding to the Little Ice Age ( 1350-1850 A.D., e.g. Wanner et al. 2008) which is also recorded for other regions of the Andes (Thompson et al. 1986; Rabatel et al. 2005; Polissar et al. 2006), even though the timing of this event is not fully resolved.

The two uppermost pollen zones are characterised by higher values of the vegetation types of Subpáramo and upper and lower mountain rainforest. This suggests that the present upper forest-line was formed in the area around this time. In zone TL-IV, Poaceae and Plantago rigida-type as highest pollen producers show both low values, thereby 
causing an elevation of the values of many other pollen taxa of the Páramo. Climate seems to be mesic at this period, as no specific group of taxa dominates the pollenspectrum. However, Alnus, Eryngium-type and Lysipomia reappear with higher values, which could be a signal of disturbance.

In zone TL-V the present conditions of the Páramo at Tres Lagunas are being established. Poaceae and Plantago rigida-type both obtain very high values and anthropogenically introduced taxa such as Pinus and Zea mays are recorded for the first time. Higher values of Isoëtes and ferns and mosses in general indicate a moist environment which is reported throughout the central to northern Andes (see Baker et al. 2001; Marchant et al. 2002; Niemann and Behling 2009 for an overview).

Fire record and early human influence in the Páramo of Quimsacocha

Human-environment relationships have a long and diverse history in the region of the central to northern Andes (Contreras 2010). In the highlands, pastoralism was practiced since pre-Columbian times (D'Altroy 2000; Sarmiento 2002). In this context, fire is and was regularly used by pastoralists and hunters of the High Andes to encourage the growth of tender forage (Cierjacks et al. 2007; Contreras 2010; Purcell and Brelsford 2004). In the Quimsacocha volcanic basin, this practice is still carried out at the present time (personal observation). However, traces of present local fire could not be confirmed in the charcoal-record, as concentrations were generally very low. Even though charcoal particles were grouped into classes of different sizes in order to be able to distinguish local from regional fires, this distinction could not be made, as bigger charcoal particles were very rare. These findings can supposedly be explained by the fact that the herbal vegetation only burns very superficially, as humid soil conditions prevent herbs and shrubs from blazing thoroughly (personal observation, see Fig. 2). Moist conditions could also lead to lower burning temperatures, which result in scorched but not completely charred particles (Whitlock and Larsen 2001). Thus, this could mean that even though fire may have caused changes in the vegetation composition of the Páramo, it cannot be detected with certainty by counting charcoal. On the other hand, lower charcoal concentrations in the present could indicate that fire activity was even higher in the past. When considering the charcoal record, fire intensity seems to have been highest during the early mid-Holocene. However, this appearance may be due to the fact that the sediment is very compressed at the corresponding depth. Therefore the charcoal record does not necessarily indicate that the most severe fires occurred during this period. Whether fires in early Holocene times were caused by humans who had been living in the central Andes since at least the late Pleistocene (Nuñez et al. 2002) is still under discussion (Weng et al. 2006). However, even nomad hunters would have made their work easier if they had used fire as a tool for hunting camelid herds, and there is no reason to doubt their ability to have done so. The earliest record of human occupation in the region of the southern Ecuadorian Andes close to the Quimsacocha volcanic basin is Chobshi Cave (8000 B.P., Lynch and Pollock 1971 in Valdez 2008), but earlier occupation of the Andes is known from the El Inga, close to Quito (11000 B.P.), and Cubilan (10000 B.P.), about $100 \mathrm{~km}$ north of Loja (Mayer-Oakes 1986; Temme 1982 in Valdez 2008).

Furthermore, not even a very early slash-and burn cultivation can be fully excluded, as the finding of a very early (9320 cal. B.P.) domestication of Cucurbita in the southwestern Coastal region illustrates (Piperno and Stothert 2003).

A further indication of fire during past times could be the absence versus the rare occurrence of Polylepis/Acae$n a$-type pollen in the palaeoecological record. Even though a distinction of the pollen grains is not possible, the pollen in this case most probably originated from the genus Polylepis, as Acaena is not recorded at high abundances in this Páramo at the present time. Polylepis occurs naturally, at least on the slopes and more protected ridges of the area, and might have had a bigger range in the past (Purcell and Brelsford 2004), even though higher abundances were not encountered in the pollen record. During the past, Polylepis-pollen was only present when moister conditions prevailed on the plateau. As Polylepis is known to be very sensitive to fire and to need a long time to regenerate (Cierjacks et al. 2007; Kessler 2002), the presence of this taxon indicates a moist period without fires, whereas its absence can suggest that more severe fires occurred during drier periods. Similar observations have also been made by Urrego et al. (2011), who report that, with the onset of fire, a reduction of forest patches took place in Southern Peru. Here, the Polylepis patches were replaced by grassland. Also, Polylepis is known to switch away from sexual reproduction when facing less favorable conditions, and so is absent from the pollen record (Gosling et al. 2009). Other taxa, such as Hypericum and Gentianella seem to be absent under similar conditions as Polylepis.

\section{Conclusions}

The record Tres Lagunas from the Quimsacocha basin in south Ecuador provides a detailed history of the vegetation and fire dynamics of the north-western Andes since the early Holocene. The period between ca. 7600 and $2200 \mathrm{cal}$. в.P. is characterised by a very low sediment accumulation 
rate which results also in very dense sediment and high pollen as well as charcoal concentrations. Sharp changes in the proxies suggest a hiatus for this period. Poaceae is the most abundant taxon during this time. All this reflects a much warmer and drier climate during the early to midHolocene, which can be observed throughout the central Andes region. The late Holocene begins with a change to cooler and moister conditions at ca. 2200 cal. B.P. in which Plantago rigida-type dominates the record. The conditions then change about 1,000 years later towards a drier habitat, which is dominated by indicators of disturbance such as Eryngium-type, Alnus and Huperzia. Then, a colder and very moist period, which could correspond to the Little Ice Age, is recorded. During the last two pollen zones, an upward shift of the upper forest-line to the present conditions can be observed. Stronger human influence is recorded especially during the last $\sim 200$ year B.P., but an early Holocene presence of fire with correlating phases of disappearance of Polylepis seem to point towards an earlier interference.

Acknowledgments We thank Corinna Brunschön, Fernando Rodriguez and Patricio Crespo for assistance in the field. We acknowledge the regional team of the FOR 816 for logistical support and Prof. Antoine Cleef for the determination of plant taxa. The comments of William Gosling and one anonymous reviewer helped to improve the quality of the manuscript. This research was supported by the Deutsche Forschungsgemeinschaft (DFG) Grant FOR 816/D1 (BE2116/8-2)

Open Access This article is distributed under the terms of the Creative Commons Attribution Noncommercial License which permits any noncommercial use, distribution, and reproduction in any medium, provided the original author(s) and source are credited.

\section{References}

Abbott M, Wolfe B, Wolfe A, Seltzer G, Aravena R, Mark B, Polissar P, Rodbell D, Rowe H, Vuille M (2003) Holocene paleohydrology and glacial history of the central Andes using multiproxy lake sediment studies. Palaeogeogr Palaeoclimatol Palaeoecol 194:123-138

AMBIGEST (Gestion Ambiental C. Ltda) (2005) IAMGOLD áreas mineras "Cerro Casco" y "Rio Falso"-Estudio ampliatorio de impacto ambiental y plan de manejo ambiental. http:// www.quimsacocha.com/. Accessed 3 Dec 2010

Ayers T (1997) Three new species of Lysipomia (Lobeliaceae) endemic to the Páramos of southern Ecuador. Brittonia 49: 433-440

Baker PA, Rigsby CA, Seltzer GO, Fritz SC, Lowenstein CK, Bacher NP, Veliz C (2001) Tropical climate changes at millennial and orbital timescales on the Bolivian Altiplano. Nature 409:698-701

Balslev H, Luteyn J (1992) Páramo: an Andean ecosystem under human influence. Academic Press, London

Beck E, Makeschin F, Haubrich F, Richter M, Bendix J, Valerezo C (2008) The ecosystem (Reserva Biológica San Francisco). In: Beck E, Bendix J, Kottke I, Makeschin F, Mosandl R (eds)
Gradients in a tropical mountain ecosystem of Ecuador. Springer, Berlin, pp 1-13

Bendix J, Rollenbeck R, Palacios WE (2004) Cloud detection in the Tropics-a suitable tool for climate-ecological studies in the high mountains of Ecuador. Int J Remote Sens 25:4,521-4,540

Berger A, Loutre MF (1991) Insolation values for the climate of the last 10 million years. Quat Sci Rev 10:297-317

Bosman A, Hooghiemstra H, Cleef A (1994) Holocene mire development and climatic change from a high Andean Plantago rigida cushion mire. Holocene 4:233-243

Brunschön C, Behling H (2009) Late Quaternary vegetation, fire and climate history reconstructed from two cores at Cerro Toledo, Podocarpus National Park, southeastern Ecuadorian Andes. Quat Res 72:388-399

Brunschön C, Haberzettl T, Behling H (2010) High-resolution studies on vegetation succession, hydrological variations, anthropogenic impact and genesis of a subrecent lake in southern Ecuador. Veget Hist Archaeobot 19:191-206

Bunting MJ (2003) Pollen-vegetation relationships in non-arboreal moorland taxa. Rev Palaeobot Palynol 125:285-298

Bush MB, Weng C (2007) Introducing a new (freeware) tool for palynology. J Biogeogr 34:377-380

Bush MB, Hansen BCS, Rodbell DT, Seltzer GO, Young KR, León B, Abbott MB, Silman MR, Gosling WD (2005) A 17,000-year history of Andean climate and vegetation change from Laguna de Chochos, Peru. J Quat Sci 20:703-714

Buytaert W, Sevink J, Deleeuw B, Deckers J (2005) Clay mineralogy of the soils in the south Ecuadorian Páramo region. Geoderma 127:114-129

Cierjacks A, Salgado S, Wesche K, Hensen I (2007) Post-fire population dynamics of two tree species in high-altitude polylepis forests of Central Ecuador. Biotropica 40:176-182

Clement AC, Seager R, Cane MA (2000) Suppression of El Niño during the Mid-Holocene by changes in the Earth's orbit. Paleoceanography 15:731

Colinvaux PA, Bush MB, Steinitz-Kannan M, Miller MC (1997) Glacial and postglacial pollen records from the Ecuadorian Andes and Amazon. Quat Res 48:69-78

Conroy JL, Overpeck JT, Cole JE, Shanahan TM, Steinitz-Kannan M (2008) Holocene changes in eastern tropical Pacific climate inferred from a Galápagos lake sediment record. Quat Sci Rev 27:1,166-1,180

Contreras DA (2010) Landscape and environment: insights from the prehispanic Central Andes. J Archaeol Res 18:241-288

Coûteaux M, Sarmiento L, Bottner P, Acevedo D, Thiéry J (2002) Decomposition of standard plant material along an altitudinal transect $(65-3,968 \mathrm{~m})$ in the tropical Andes. Soil Biol Biochem 34:69-78

D'Altroy TN (2000) Andean land use at the cusp of history. In: Lentz DL (ed) Imperfect balance: landscape transformations in the Precolumbian Americas. Columbia University Press, New York, pp 357-390

De Toledo MB, Bush MB (2007) A mid-Holocene environmental change in Amazonian savannas. J Biogeogr 34:1,313-1,326

Emck P (2007) A Climatology of South Ecuador-with special focus on the Major Andean Ridge as Atlantic-Pacific Climate Divide. Dissertation, University Erlangen-Nürnberg

Fægri K, Iversen J (1989) Textbook of pollen analysis. Wiley, Chichester

Farley K (2007) Grasslands to tree plantations: forest transition in the Andes of Ecuador. Ann Assoc Am Geogr 97:755-771

Finsinger W, Tinner W, Hu F (2008) Rapid and accurate estimates of microcharcoal content in pollen slides. In: Fiorentino G, Magri D (eds) Charcoals from the past: cultural and palaeoenvironmental implications: proceedings of the Third International Meeting of 
Anthracology, Cavallino-Lecce (Italy) 2004. Hadrian Press, Oxford, pp 121-124

Gosling WD, Hanselman JA, Knox C, Valencia BG, Bush MB (2009) Long-term drivers of change in Polylepis woodland distribution in the central Andes. J Veget Sci 20:1,041-1,052

Grimm E (1987) CONISS: a Fortran 77 program for stratigraphically constrained cluster analysis by the method of the incremental sum of squares. Comput Geosci 13:13-35

Hansen B, Rodbell D, Seltzer G, Leon B, Young K, Abbott M (2003) Late-glacial and Holocene vegetational history from two sites in the western Cordillera of southwestern Ecuador. Palaeogeogr Palaeoclimatol Palaeoecol 194:79-108

Harden C (2007) Two soil toposequences in a tropical glacial trough, southern Ecuador. Zeitschr Geomorph, Suppl Iss 51:139-152

Haug GH, Hughen KA, Sigman DM, Peterson LC, Röhl U (2001) Southward migration of the intertropical convergence zone through the Holocene. Science 293:1,304-1,308

Hicks S, Tinsley H, Huusko A, Jensen C, Hättestrand M, Gerasimides A, Kvavadze E (2001) Some comments on spatial variation in arboreal pollen deposition: first records from the Pollen Monitoring Programme (PMP). Rev Palaeobot Palynol 117:183-194

Hillyer R, Valencia BG, Bush MG, Silman MR, Steinitz-Kannan M (2009) A 24,700-yr paleolimnological history from the Peruvian Andes. Quat Res 71:71-82

Hofstede RGM, Groenendijk JP, Coppus R, Fehse J, Sevink J (2002) Impact of pine plantations on soils and vegetation in the Ecuadorian High Andes. Mt Res Dev 22:159-167

Homeier J, Werner FA, Gradstein SR, Breckle S-W, Richter M (2008) Potential vegetation and floristic composition of Andean forests in South Ecuador, with a focus on the RBSF. In: Beck E, Bendix J, Kottke I, Makeschin F, Mosandl R (eds) Gradients in a tropical mountain ecosystem of Ecuador. Springer, Berlin, pp 87-100

Hooghiemstra H (1984) Vegetation and Climatic History of the High Plain of Bogota, Colombia. Cramer, Vaduz

Hungerbühler D, Steinmann M, Winkler W, Seward D, Egüez A, Peterson DE, Helg U, Hammer C (2002) Neogene stratigraphy and Andean geodynamics of southern Ecuador. Earth Sci Rev 57:75-124

Ise T, Dunn AL, Wofsy SC, Moorcroft PR (2008) High sensitivity of peat decomposition to climate change through water-table feedback. Nat Geosci 1:763-766

Jørgensen P, León-Yánez S (1999) Catalogue of the vascular plants of Ecuador. Missouri Botanical Garden, St. Louis

Kessler M (2002) The "Polylepis Problem": where do we stand? Ecotropica 8:97-110

Luteyn JL (1999) Páramos: a checklist of plant diversity, geographical distribution and botanical literature. Memoirs of the New York Botanical Garden, Bronx

Lynch T, Pollock S (1971) La arqueología de la Cueva Negra de Chobshi. Miscelánea Antropológica Ecuatoriana 1:92-119

Marchant R, Behling $\mathrm{H}$, Berrio J, Cleef A, Duivenvoorden J, Hooghiemstra H, Kuhry P, Melief B, Schreve-Brinkman E, Van Geel B, Van der Hammen T, Van Reenen G, Wille M (2002) Pollen-based biome reconstructions for Colombia at 3000, 6000, $9000,12000,15000$ and $1800014 \mathrm{C}$ yr ago: late quaternary tropical vegetation dynamics. J Quat Sci 17:113-129

Mayer-Oakes WJ (1986) El Inga, a Paleo-Indian site in the Sierra of Northern Ecuador. Trans Am Philosoph Soc 76:1-235

Mitchell TP, Wallace JM (1991) The annual cycle in equatorial convection and sea surface temperature. J Clim 5:1,140-1,156

Mosandl R, Günter S, Stimm B, Weber M (2008) Ecuador suffers the highest deforestation rate in South America. In: Beck E, Bendix J, Kottke I, Makeschin F, Mosandl R (eds) Gradients in a tropical mountain ecosystem of Ecuador. Springer, Berlin, pp 37-40
Moy CM, Seltzer GO, Rodbell DT, Anderson DM (2002) Variability of El Niño/Southern Oscillation activity at millennial timescales during the Holocene epoch. Nature 420:162-165

Niemann H, Behling H (2008) Late Quaternary vegetation, climate and fire dynamics inferred from the El Tiro record in the southeastern Ecuadorian Andes. J Quat Sci 23:203-212

Niemann H, Behling H (2009) Late Pleistocene and Holocene environmental change inferred from the Cocha Caranga sediment and soil records in the southeastern Ecuadorian Andes. Palaeogeogr Palaeoclimatol Palaeoecol 276:1-14

Nuñez L, Grosjean M, Cartajena I (2002) Human occupations and climate change in the Puna de Atacama, Chile. Science 298:821-824

Paduano G, Bush M, Baker P, Fritz S, Seltzer G (2003) A vegetation and fire history of Lake Titicaca since the Last Glacial Maximum. Palaeogeogr Palaeoclimatol Palaeoecol 194:259-279

Piperno DR, Stothert K (2003) Phytolith evidence for early Holocene Cucurbita Domestication in Southwest Ecuador. Science 299:1,054-1,057

Planiglobe beta (2011) http://www.planiglobe.com. Accessed 16 July 2011

Podwojewski P, Poulenard J, Zambrana T, Hofstede R (2002) Overgrazing effects on vegetation cover and properties of volcanic ash soil in the páramo of Llangahua and La Esperanza (Tungurahua, Ecuador). Soil Use Manag 18:45-55

Polissar PJ, Abbott MB, Wolfe AP, Bezada M, Rull V, Bradley RS (2006) Solar modulation of Little Ice Age climate in the tropical Andes. Proc Nat Acad Sci 103:8,937-8,942

Purcell J, Brelsford A (2004) Reassessing the causes of decline of Polylepis, a tropical subalpine forest. Ecotropica 10:155-558

Rabatel A, Jomelli V, Naveau P, Francou B, Grancher D (2005) Dating of Little Ice Age glacier fluctuations in the tropical Andes: Charquini glaciers, Bolivia, $16^{\circ} \mathrm{S}$. Comp Rend Geosci 337:1,311-1,322

Ramsay PM, Oxley E (1996) Fire temperatures and postfire plant community dynamics in Ecuadorian grass Páramo. Vegetatio 124:129-144

Ramsay PM, Oxley E (1997) The growth form composition of plant communities in the ecuadorian Páramos. Plant Ecol 131:173-192

Rodbell D (2002) A late glacial-Holocene tephrochronology for Glacial Lakes in Southern Ecuador. Quat Res 57:343-354

Roubik DW, Moreno JE (1991) Pollen and spores of Barro Colorado Island. Missouri Botanical Garden, St. Louis

Sadori L, Giardini M (2007) Charcoal analysis, a method to study vegetation and climate of the Holocene: the case of Lago di Pergusa (Sicily, Italy). Geobios 40:173-180

Sarmiento FO (2002) Anthropogenic change in the landscapes of highland Ecuador. Geogr Rev 92:213-234

Sklenáŕ P (2005) Superpáramo plant species diversity and phytogeography in Ecuador. Flora 200:416-433

Sklenár P, Balslev H (2007) Geographic flora elements in the Ecuadorian Superpáramo. Flora 202:50-61

Sklenár P, Ramsay PM (2001) Diversity of zonal Páramo plant communities in Ecuador. Divers Distrib 7:113-124

Temme M (1982) Excavaciones en el sitio precerámico de Cubilan (Ecuador). Miscelánea Antropológica Ecuatoriana 2:135-165

Ter Braak C, Šmilauer P (2002) CANOCO Reference manual and CanoDraw for Windows User's Guide: Software for Canonical Community Ordination (version 4.5). Microcomputer Power, Ithaka

Thompson LG, Mosley-Thompson E, Dansgaard W, Grootes PM (1986) The Little Ice Age as Recorded in the Stratigraphy of the Tropical Quelccaya Ice Cap. Science 234:361-364 
Tweddle JC, Edwards KJ (2010) Pollen preservation zones as an interpretative tool in Holocene palynology. Rev Palaeobot Palynol 161:59-76

Urrego DH, Niccum BA, La Drew CF, Silman MR, Bush MB (2011) Fire and drought as drivers of early Holocene tree line changes in the Peruvian Andes. J Quat Sci 26:28-36

Valdez F (2008) Inter-zonal relationships in Ecuador. In: Silverman H, Isbell WH (eds) Handbook of South American archeology. Springer, New York, pp 865-888

Valencia BG, Urrego DH, Silman MR, Bush MB (2010) From ice age to modern: a record of landscape change in an Andean cloud forest. J Biogeogr 37:1,637-1,647

Wanner H, Beer J, Butikofer J, Crowley TJ, Cubasch U, Flückiger J, Goosse H, Grosjean M, Joos F, Kaplan JO, Küttel M, Müller SA, Prentice IC, Solomina O, Stocker TF, Tarasov P, Wagner M, Widmann M (2008) Mid- to Late Holocene climate change: an overview. Quat Sci Rev 27:1,791-1,828
Weng C, Bush MB, Chepstow-Lusty AJ (2004) Holocene changes of Andean alder (Alnus acuminata) in highland Ecuador and Peru. J Quat Sci 19:685-691

Weng C, Bush MB, Curtis JH, Kolata AL, Dillehay TD, Binford MW (2006) Deglaciation and Holocene climate change in the western Peruvian Andes. Quat Res 66:87-96

Weninger B, Jöris O, Danzeglocke U (2010) Cologne Radiocarbon CALibration \& PALeoclimate Research Package. http:// calpal.de/ Accessed 25 April 2010

Whitlock C, Larsen C (2001) Charcoal as a fire proxy. In: Smol JP, Birks HJB, Last WM (eds) Tracking environmental change using lake sediments. Kluwer, Dordrecht, pp 75-98

Wilmshurst JM, McGlone MS (2005) Corroded pollen and spores as indicators of changing lake sediment sources and catchment disturbance. J Paleolimnol 34:503-517 